\title{
PSIGIATRIESE VERPLEEGVAARDIGHEDE IN ANDER VERPLEEGDIMENSIES
}

\section{Referaat gelewer by die simposium Verpleging in die jare tagtig aangebied by die Randse Afrikaanse Universiteit. MARIE POGGENPOEL}

\section{SUMMARY}

Psychiatric nursing is a specialised area of nursing practice which has a scientific base and in which the nurse uses herself as a therapeutic instrument in the implementation of the nursing process.

This requires knowledge, self-knowledge, positive attitudes, therapeutic communication skills and the use of therapeutic nursing methods such as interviewing, group therapy and mental health counselling.

Nurses who work in other areas of nursing can apply the above skills in their professional task, as well as at personal level.

\section{INLEIDING}

Psigiatriese verpleegkunde is 'n gespesialiseerde area van verpleegpraktyk wat berus op 'n wetenskaplike basis en die doelgerigte gebruik van die verpleegkundige self as persoon. Psigiatriese verpleegkunde is gerig op voorkomende sowel as herstellende aspekte van geestesongesteldheid en die bevordering van optimale geestesgesondheid vir die individu, familie, gemeenskap en die samelewing. Die psigiatriese dienste, dus ook die psigiatriese verpleegpraktyk, is'n integrale deel van omvattende gesondheidsorg. Psigiatriese verpleegkunde is hoofsaaklik gebaseer op interpersoonlike kontak tussen die verpleegkundige en individue en groepe ( $\mathrm{Pog}-$ genpoel, 1982:18).

Wanneer verwys word na psigiatriese verpleegvaardighede word hierdie vaardighede as integrale deel beskou van die psigiatriese verpleegkundige se gebruikmaking van haarself as terapeutiese instrument in kontak met hulpbehoewende individue in die uitvoering van die verpleegproses. Die verpleegkundige se mensbeskouing beïnvloed haar vermoë om effektief te kan funksioneer (Poggenpoel, 1982:140).

Dr. M. Poggenpoel, BA(Soc Sc) (PU vir $\mathrm{CHO}$ ), M(Soc Sc)(Psig. Verpleegkunde)(UOVS), DPhil(PU vir CHO), GAV, GVV, GPV, GGV, VOnd.

Lektriese, Departement Verpleegkunde, Randse Afrikaanse Universiteit
Die psigiatriese verpleegkundige het spesifieke kennis, houdings en vaardighede nodig om haarself as terapeutiese instrument te gebruik (Okun, 1982: Wilson \& Kneisl, 1983:144 en 145, Haber, Leach, Schudy en Sideleau, 1978:8).

Hierdie kennis, houdings en vaardighede kan nie as aparte entiteite beskou word nie omdat hulle ineenskakel om 'n geheel te vorm waardeur die psigiatriese verpleegkundige interaksies daarstel wat persone se gesondheid en welstand bevorder (Aiken en Aiken, 1973:864) (Sien figuur 1).

Vervolgens sal die kennis, selfkennis, houdings, vaardighede en metodes wat deel is van die effektiewe gebruikmaking van die psigiatriese verpleegkundige as terapeutiese instrument bespreek word. Laastens sal verwys word na hoe hierdie veskillende aspekte toegepas word in ander verpleegdimensies.

KENNIS

Kennis in hierdie verband verwys na teoretiese kennis en selfkennis.

Figuur 1 Die Psigiatriese verpleegkundige se gebruikmaking van self as terapeutiese instrument

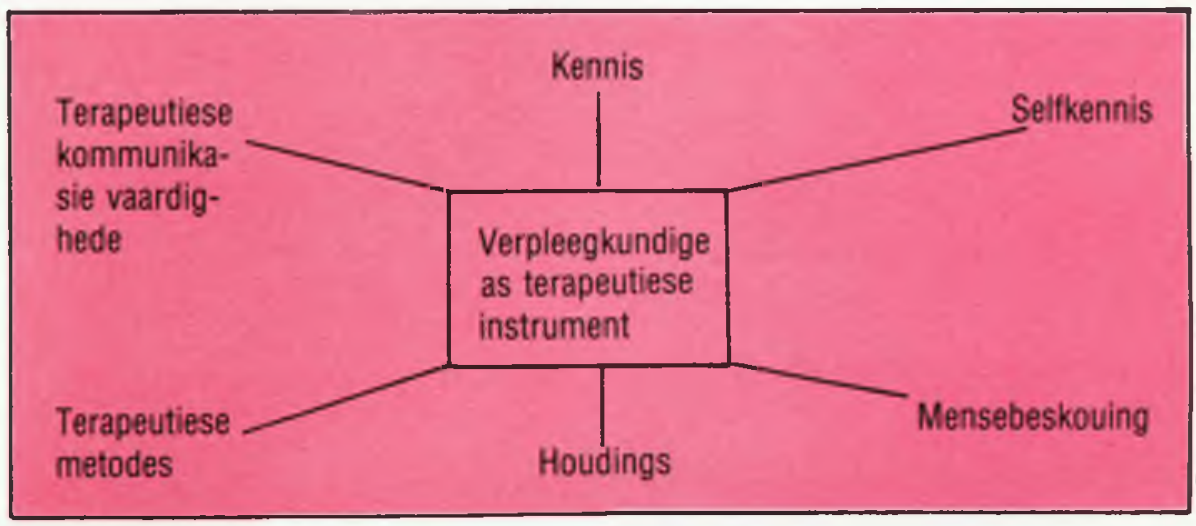

Figuur 2: Kontinuum van geestesgesondheid

\begin{tabular}{|c|c|c|}
\hline Minimaal & Ekwilibrium & Maksimaal \\
\hline & $\begin{array}{c}\text { Gesonde aanpassing by spanning } \\
\text { - Selfverwesenliking } \\
\text { - Emosionele volwassenheid }\end{array}$ & \\
\hline
\end{tabular}


As geestesongesteldheid skematies voorgestel word op 'n kontinuum lyk dit soos uitgebeeld in figuur 3 .

\section{Selfkennis}

Elke verpleegkundige moet bewus wees van sy eie houdings, behoeftes, persoonlikheidstyl, interpersoonlike bates en talente. 'n Verpleegkundige moet haar eie gevoelens, houdings en optredes gedurigdeur ondersoek.

Jou persoonlikheid verteenwoordig jou unieke identiteit. Dit is belangrik dat die verpleegkundige haar eie natuurlike gedragstyl verstaan en ontwikkel want dit dra daartoe by dat sy in interpersoonlike verhoudinge veilig voel. Die self tree in interaksie met andere na vore en beînvloed daardie sosiale en professionele interaksies. 'n Verpleegkundige se selfkennis is afhanklik van die wyse waarop sy met andere in interaksie tree.

Om selfkennis, wat 'n noodsaaklike voorvereiste vir die daarstelling van positiewe interpersoonlike verhoudinge te bekom is dit noodsaaklik om selfbewussyn (Brammer, 1979:26-29, Lore, 1981:19-23, Jourard, 1971:27-33, Murray en Heulskotter, 1983, 13, 98100, Burgess en Lazare, 1976:108 en 109, Kreigh en Perko, 1983:208 en 209. Wilson en Kneisl, 1983:42-50, Okun, 1982:34) te ontwikkel.

In die opleiding van die psigiatriese verpleegkundige word nadruk gelê op die ontwikkeling van selfkennis omdat dit 'n voorvereiste is om die self as 'n terapeutiese instrument te kan gebruik. In die proses van ontwikkeling van selfkennis is dit belangrik om eie behoeftes, stand ten opsigte van interpersoonlike strelings, lewensposisies, egotoestande, interpersoonlike patroon van gedrag en selfhandhawende gedrag vas te stel.

\section{Universele behoeftes van die mens}

'n Behoefte kan gesien word as 'n tekort wat met die normale funksionering van die mens inmeng. Hierdie tekorte dwing die persoon om op te tree om die effek van die tekort uit te skakel. Volgens Maslow (1954:84-97) het alle mense die volgende behoeftes: fisiologies, sekuriteit en veiligheid, liefde en behoort aan, selfwaarde- en erkenning. waarde en selfverwesenliking. Hierdie behoeftes kom in 'n hiërargiese volgorde voor.

Figuur 3: Kontinuum van geestesongesteldheid

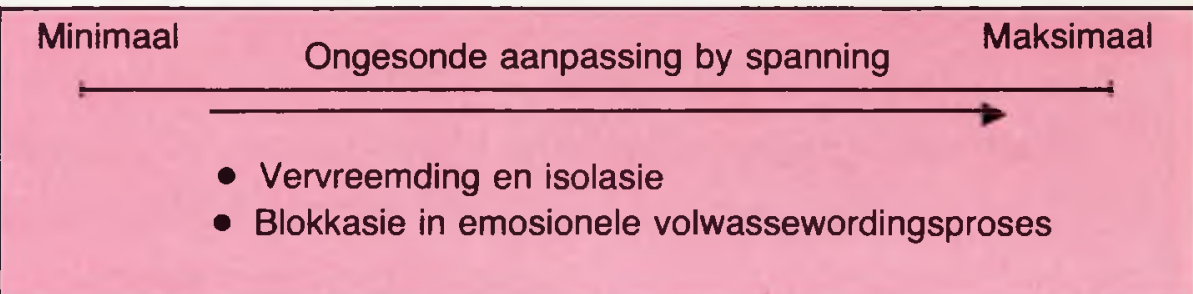

Figuur 4: Die Johari venster: Skema van selfkennis (Wilson \& KneisI, 1983:49)

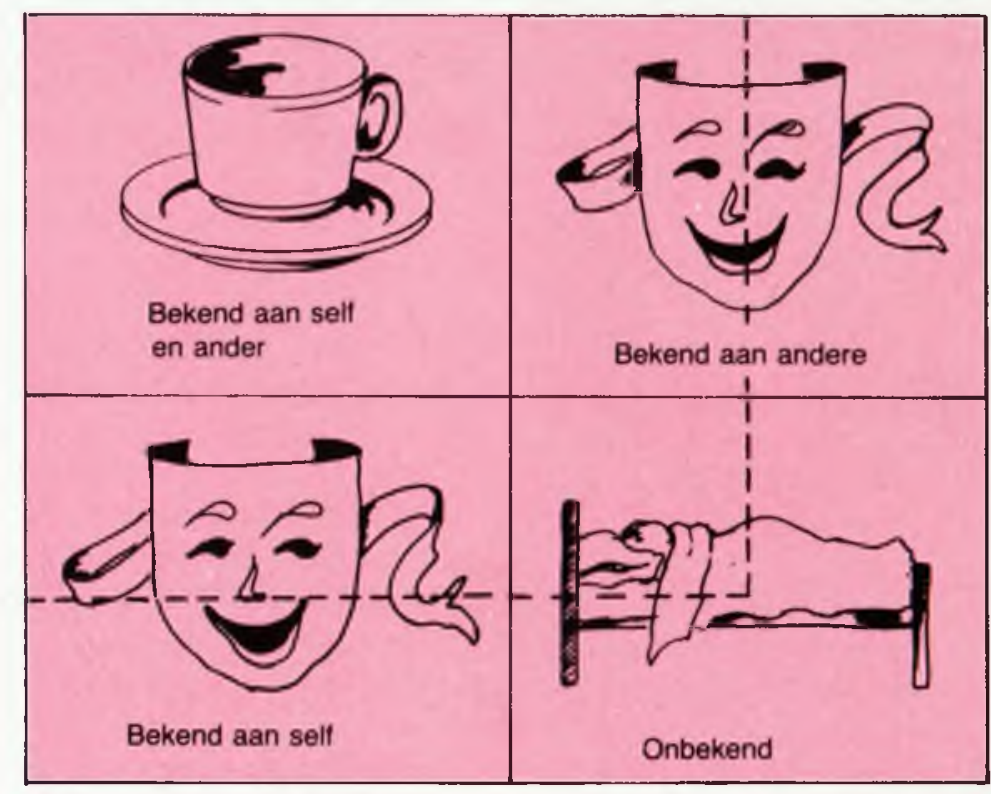

Figuur 5: Maslow se hiërargie van behoeftes (Irving, 1954:84-97)

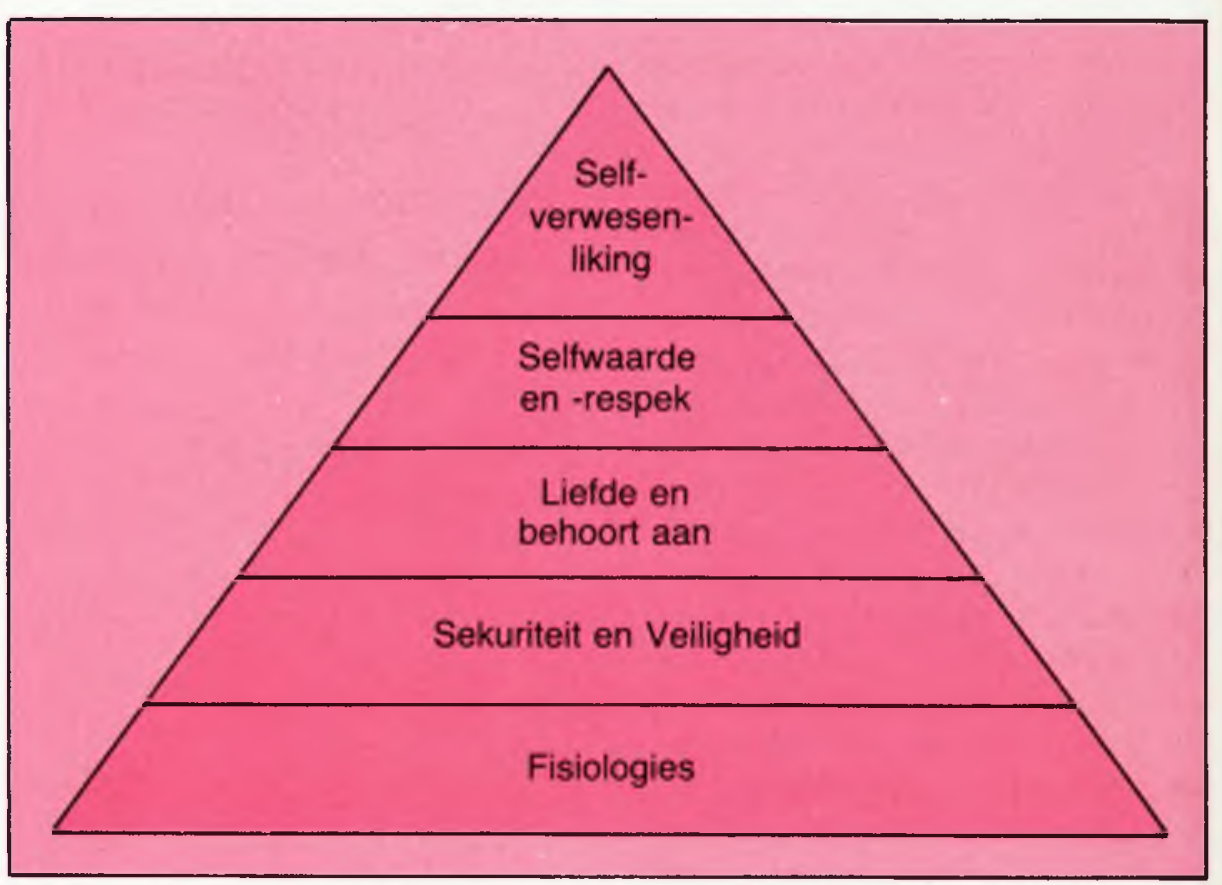

As die behoeftes van een groep nie bevredig word nie bemvloed dit dan weer die volgende groep behoeftes. Daar is ook nog die behoefte aan kennis en estetiese behoeftes.

Volgens ander skrywers het die mens geestelike behoeftes (Carson, 1980:118) en die behoefte aan sin en betekenis in die lewe (Frankl, 1963:171). Wanneer daar 'n blokkasie in die weg van behoeftebevrediging kom word 'n probleem geskep wat spanning veroorsaak. Dit is dus belangrik dat die verpleegkundige bewus is van haar eie behoeftes en ook in staat is om die behoeftes van die persoon wat vir hulp kom te identifiseer. 


\section{Strelings in interpersoonlike interaksies}

Die beginsel streling (sien figuur 6) is inherent aan die begrip transaksie ('n uitruiling van streling tussen twee mense) wat mense aangaan wanneer hulle kommunikeer. 'n Streling is iets wat ons almal moet ontvang, of dit nou positief of negatief is.

As babas en kinders het meeste van ons letterlik positiewe strelings ontvang - soene, omhelsings, drukkies - wat ons goed laat voel het. Ons het soms negatiewe strelings ontvang in die vorm van fisiese straf of raas - en so sleg as wat dit ons laat voel het was dit verkieslik bo geen strelings nie.

Later in die lewe hou ons aan om na strelings te soek in die vorm van erkenning- soos 'n groet, 'n kompliment oor ons voorkoms en prys oor optrede. Ons kan egter negatiewe strelings soek as daar geen ander vorm van streling beskikbaar is nie. Dit is dus vir elkeen van ons belangrik om te weet watter rol strelings in ons lewe speel om ons goed te laat voel. (albano, 1974:16)

\section{Egotoestande as deel van self in die kommunikasieproses}

Elke persoon het drie hoofbronne van gedrag of egotoestande - die Ouer, die Volwassene en Kind. Dit is belangrik om te bepaal watter egotoestand jou gedrag op 'n spesifieke tyd beheer.

Spontaneiteit, sjarme, kreatiwiteit en genot is deel van die Kind. Die Volwassene is nie slegs daar vir oorlewing en

Figuur 7: Egotoestande (Wilson \& Kneisl, 1983 : 116)

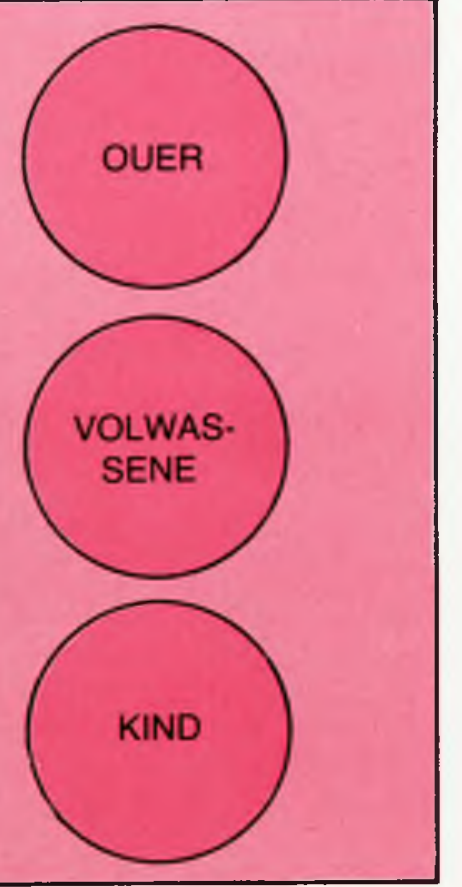

Figuur 6: Positiewe en negatiewe "strelings"

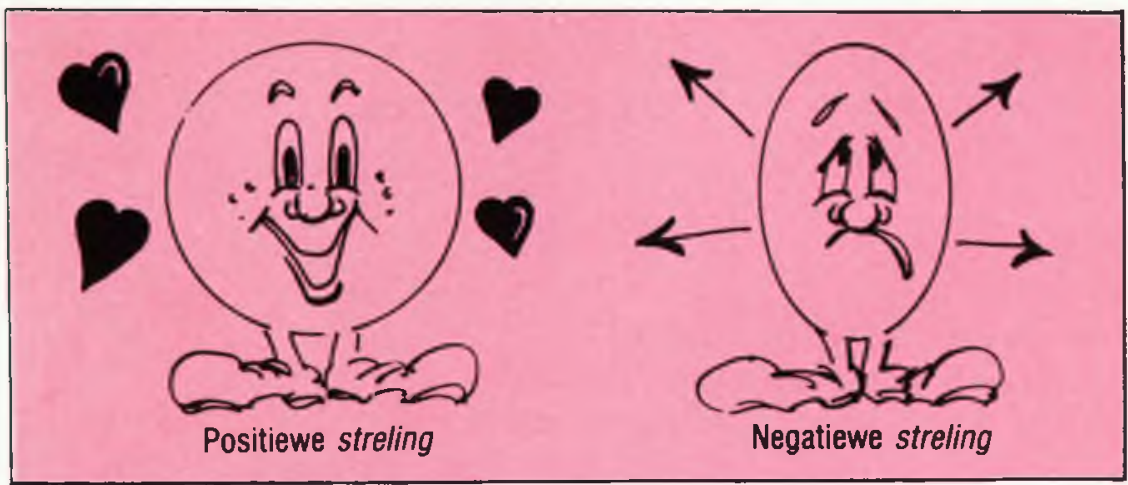

om die buitewêreld effektief te hanteer nie, maar beheer ook die aktiwiteite van die Ouer en Kind. Die Ouer stel die individu in staat om effektief as ' $n$ ouer op te tree en maak baie response wat die Volwassene van roetine en nietige besluite vrystel. Elk van die drie egotoestande verrig belangrike funksies (Albano, 1974:16, Irving. 1978:12-19. Wilson en Kneisl, 1983:116-121) (Sien ook figuur 8).

\section{Lewensposisies}

Die wyse waarop ons oor onsself en ander mense voel bepaal tot ' $n$ groot mate die soort transaksies wat ons met ander mense aangaan. Daar is vier soorte lewensposisies waarin ons kan funksioneer. Dit is belangrik om die implikasies van elkeen te besef as ons rekenskap vir ons gedrag wil gee en ons eie response wil bemeester. Alhoewel

Figuur 8: Twee komplementêre transaksies (Wilson \& Kneisl, 1983:119)

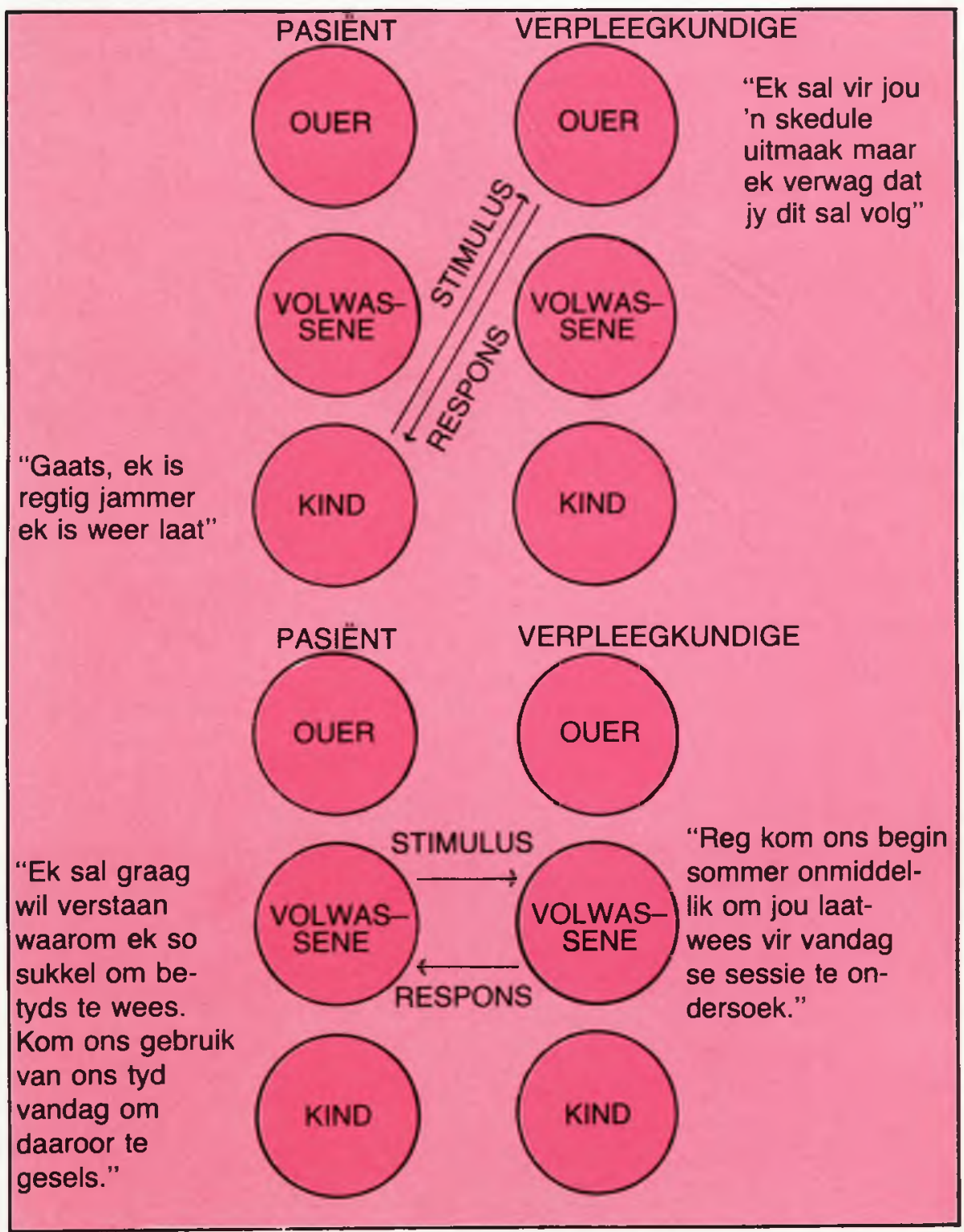


hierdie posisies in volwassenheid hoofsaaklik op 'n onbewuste vlak werk is hulle onderliggend aan al ons gedrag.

Die vier lewensposisies word in figuur is uitgebeeld en is as volg:

\section{Ek's OK - Jy's OK}

Hierdie persoon bied vreugde aan almal wat met hom betrokke raak. Hy het in volwassenheid op hierdie posisie besluit. Dit laat hom toe om sy vermoëns uit te leef en sy doelstellings in die lewe te bereik. Hy hoef nie op die voorhou van 'n beskermende front energie te verspil nie en voel nie genoop om die OK-heid van ander mense te kontroleer nie.

\section{Ek's nie OK - Jy's OK}

Hierdie persoon neem 'n soort onderdanige, selfnederlagende posisie in ' $n$ verhouding met andere. Dit is ' $\mathrm{n}$ verloorder se posisie, die persoon voel minderwaardig en dit is onwaarskynlik dat hy ooit geluk sal bekom al bereik hy 'n mate van sukses. Wat ook al gebeur is dit vir hom moeilik om goed oor homself te voel.

\section{Ek's nie OK - Jy's nie OK}

Hierdie is 'n lewensposisie wat baie moeilik is om te hanteer omdat dit so negatief teenoor die self en ander is.

\section{Ek's OK - Jy's nie OK}

Hierdie is 'n lewensposisie waarin die persoon goed voel oor homself maar andere wantrou en neerkyk op hulle. (Albano, 1974:53-60)

\section{Interpersoonlike patrone van gedrag}

Meeste mense neig of om daarvan te hou om dinge te beheer (hoë dominasie) of om ander toe te laat om dinge te beheer (lae dominasie). Soortgelyk neig meeste mense om of baie warm en persoonlik te wees (hoë sosialiteit) of ietwat koud en onpersoonlik te wees (lae sosialiteit). Lae sosialiteit lei tot blokkasie in interpersoonlike verhoudinge. Die persoon gebruik nie die geleentheid om terugvoer van andere te ontvang en te werk aan eie gedrag om eie potensiaal ten volle te verwesenlik nie. Om effektief terapeuties te kan wees moet die verpleegkundige streef om hoë sosialiteitsgedrag te toon.

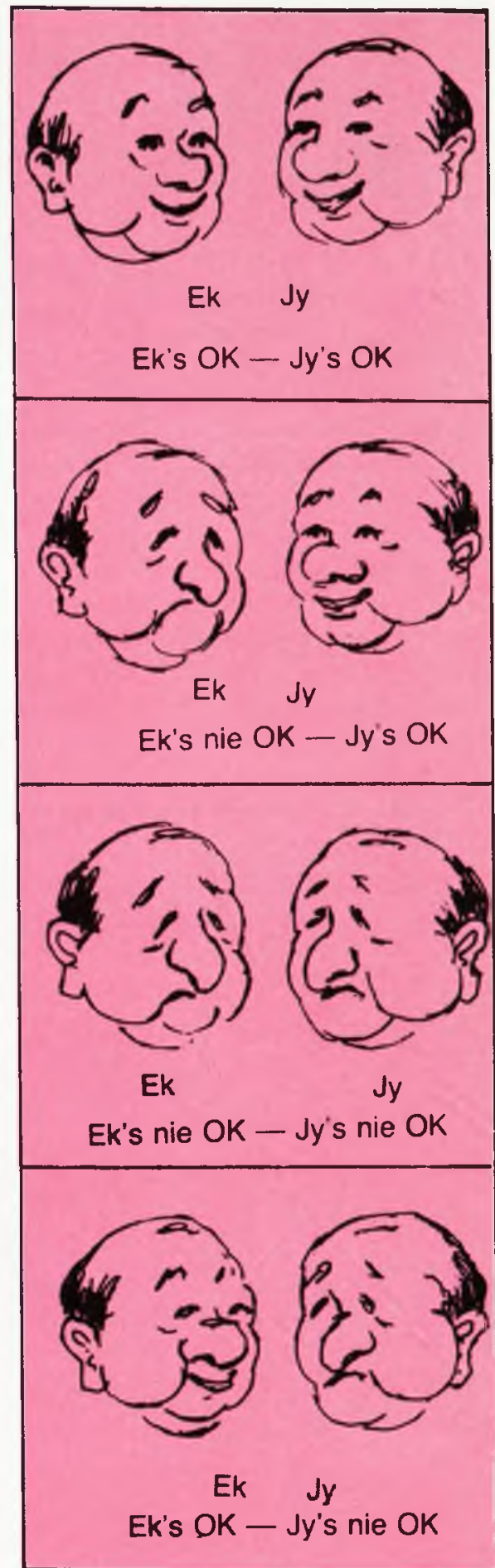

Figuur 10 Hoë en lae sosialiteit.

\section{Selfhandhawing}

Selfhandhawende gedrag stel die verpleegkundige in staat om haarself te verdedig sonder onnodige angs en om haar regte uit te voer sonder om die regte van ander te ontken. (Liberman, King, De Risi \& Mc Cann, 1975:6-8, Travers, Bryant \& Argyle, 1978:82-85)

Selfbewuswording is noodsaaklik om selfkennis te bekom. Deurdat die psigiatriese verpleegkundige haarself ken is sy in staat om positiewe interpersoonlike verhoudinge te handhaaf en om haar eie potensiaal as terapeutiese instrument te ontwikkel.

\section{HOUDINGS}

Die verpleegkundige se mensbeskouing beînvloed die wyse waarop sy mense wat in nood is sal benader (Poggenpoel, 1982:140). Navorsing het aangedui dat effektiewe helpers (dus ook verpleegkundiges) veral die volgende houdings openbaar: empatie, onvoorwaardelike aanvaarding en kongruensie.

\section{Empatie}

Empatie dui op 'n begrip van die hulp. behoewende se verwysingsraamwerk. Die terapeut dra ook oor dat sy die hulpbehoewende se probleme vanuit sy uitgangspunt probeer voel en begryp.

Deur primêre empatie gee die verpleegkundige aandag, luister en reflekteer om akkurate persepsie aan die hulpbehoewende weer te gee. Deur ge vorderde akkurate empatie beïnloed die verpleegkundige die hulpbehoewende deur selfblootstelling, riglyne of interpretasie.

\section{Kongruensie}

Die verpleegkundige praat en tree kongurent op, met ander woorde sy doen wat sy sê.

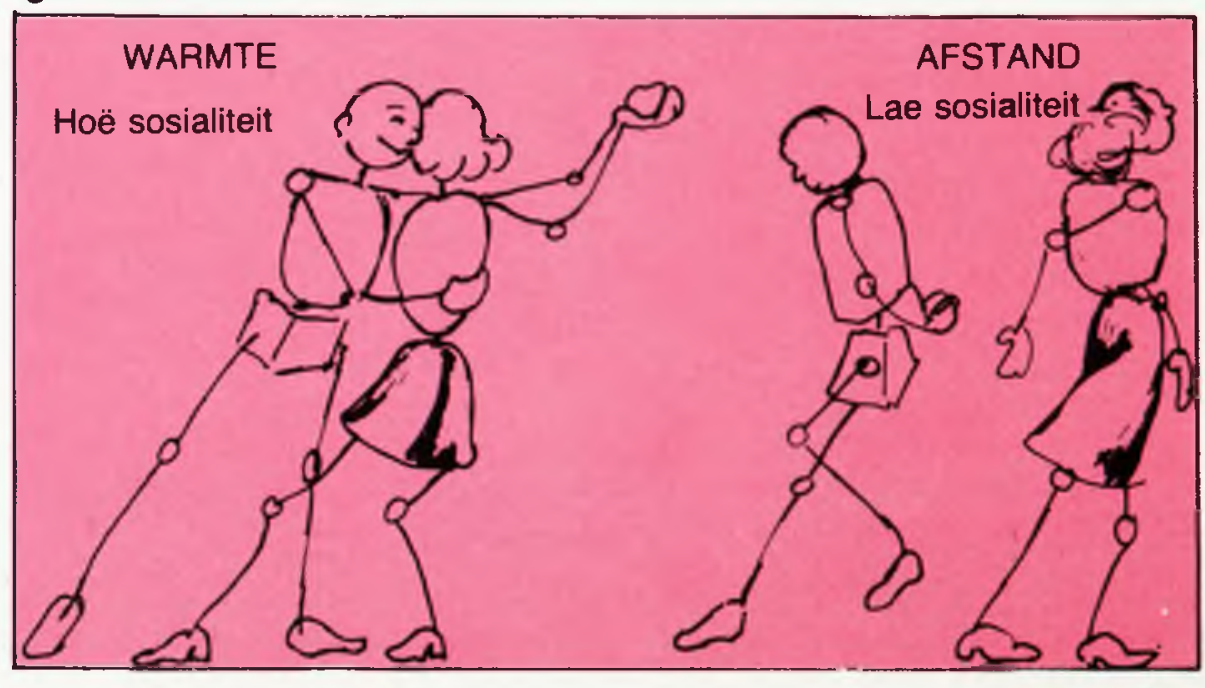


Figuur 11: Suksesvolle kommunikasie

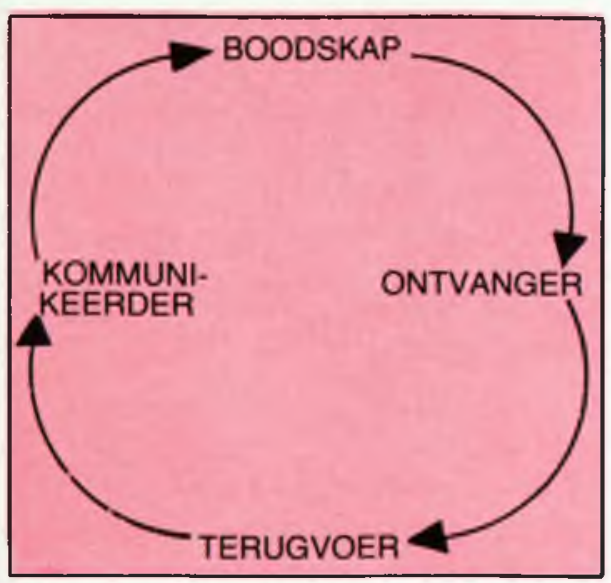

Onvoorwaardelike aanvaarding

In verpleegkunde dui dit op die oordra van aanvaarding van hulpbehoewendes as waardevolle mense, wie hulle ook al is of wat hulle ook al sê of doen. (Brammer, 1979:36-41. Murray \& Heulskotter, 1983:187-191, Kreigh \& Perko. 1983:224-227. Weiner, 1975:24-29, Wilson \& Kneisl, 1983:51-55).

\section{TERAPEUTIESE PSIGIA- TRIESE VAARDIGHEDE}

Primêre terapeutiese psigiatriese verpleegvaardighede sluit die voorafgaande kennis en houdings in. Hierdie vaardighede word deur terapeutiese kommunikasie en die gebruikmaking van terapeutiese metodes in kontak met individue en groepe beoefen.

\section{Terapeutiese kommunikasie}

In kommunikasie stuur die sender 'n boodskap wat die interpersoonlike proses in werking stel. In suksesvolle kommunikasie moet die ontvanger van die boodskap die bedoeling sowel as die invloed van die boodskap korrek verstaan en daarop reageer.

Terapeutiese kommunikasie verskil van die sosiale kommunikasieproses daarin dat die boodskappe wat gestuur en ontvang word ontwerp is om presenterende probleme en spanningsvolle lewenssituasies te hanteer, die hulpbehoewende te help om hanteringsvermoëns te leer gebruik of vermeerder en om egokragte te ontwikkel of te versterk. Kreigh \& Perko, 1983:232, Irving. 1978:25-37. Brammer, 1979:67, Lore, 1981: 47-92. Egan, 1982:35-37 \& 39-41. Mereness \& Taylor, 1978:74-87, Murray \& Heulskoetter, 1983: 151-175, Wilson \& Kneisl, 1983:103-132).
Daar is basies drie kommunikasievaardighede wat die psigiatriese verpleegkundige gebruik, naamlik hoor van verbale boodskappe, waarneem van nie-verbale boodskappe en verbale en nie-verbale response.

\section{Hoor van verbale boodskappe}

Verbale boodskappe is die opvallende en onderliggende kognitiewe en effektiewe inhoud van die hulpbehoewende se verklarings. Begrip van die inhoud is gewoonlik sekondêr tot die begrip van die gevoelens wat deur die hulpbehoewende oorgedra word.

\section{Waarneming van nie-verbale boodskappe}

Nie-verbale boodskappe verwys na liggaamstaal, stemtoon, gesiguitdrukkings en ander leidrade wat verbale boodskappe vergesel. Die verpleegkundige leer om verskille tussen verbale en nieverbale boodskappe te herken en die hulpbehoewende se bewustheid van hierdie verskille te ontwikkel.

\section{Verbale en nie-verbale response}

Responsiewe luister is om verbaal en nie-verbaal op beide die opvallende en onderliggende gedagtes en gevoelens van die hulpbehoewende te reageer op 'n onmiddellike, egte, konkrete en empatiese wyse.

Die mees algemene verbale response is minimale verbale respons, parafrasering, ondersoek, reflektering, opklaring, uitkontrolering, interpretering. konfrontering, bied van inligting, opsomming en terugvoer. (Okun, 1982:15 \& 44-82)

\section{Die gebruik van psigiatriese verpleegterapeutiese me- todes in die implementering van psigiatriese verpleeg- vaardighede}

Vir die psigiatriese verpleegkundige om haarself as terapeutiese instrument in die verpleegproses te gebruik maak sy ook gebruik van verskeie verpleegterapeutiese metodes: onderhoudsvoering. individuele verpleegterapie, groepsverpleegterapie, krisisingryping en ondersteuning, terapeutiese milieu en geestesgesondheidsonderrig.

\section{Onderhoudsvoering}

Hierdie metode help die verpleegkundige om inligting te bekom en te bied, om te onderrig, die gevoelens van andere te beraam, 'n terapeutiese verhouding op te bou en in stand te hou en probleme op te klaar. (French, 1983:124, Murray \& Heulskoetter, 1983:163, Brammer. 1979:45 \& 47).

\section{Individuele verpleegterapie}

Individuele verpleegterapie dui op " . . . an interpersonal process in which one person facilitates the personal development or growth of another over time by assisting that person to be mature; or become more adaptive, integrated and open to personal experience and to find meaning in the present situation" (Murray \& Heulskoetter. 1983:186).

Hierdie individuele verpleegterapie vind deur in aantal opeenvolgende interaksies tussen 'n verpleegkundige en pasiënt oor 'n tydperk plaas. Die verpleegkundige fokus op die behoeftes van die persoon, gesin en groep en gebruik wetenskaplike kennis en spesifieke vaardighede van die verpleegprofessie. (Murray \& Heulskoetter. 1983:186, Brammer, 1979:44-66. Egan. 1982:44-47. Kreigh \& Perko, 1983:269284, Weiner, 1975:3-6, Wilson \& Kneisl, 1983:137-165).

\section{Groepsterapie}

Groepsterapie is 'n gestruktureerde of semi-gestruktureerde proses van terapeutiese tussentrede waarin die gedrag en emosionele reaksies van die individuele lede van die groep teenoor mekaar en teenoor die leier erken en begryp word as projeksies van individuele interpersoonlike nood. Deelname in groepsterapie bied 'n heropvoedingsondervinding waarin die individu as aparte self en die groep as kollektiewe self in 'n proses van leer en probleemoplossing betrokke is. Die doel is om emosionele en gedragsreaksies noodsaaklik vir die meebring van verandering binne hulself en met die groep te hanteer. (Kreigh \& Perko 1983: 294-313, Mereness \& Taylor, 1978: 146-160. Murray \& Heubkoetter. 1983:331-366, Grace, Layton \& Camillen, 1977:365-387. Wilson \& Kneisl, 1983:214-234)

Die psigiatriese verpleegkundige gebruik haar kennis van die groepsproses om die doel van groepsterapie te bereik (Sien ook figuur 12). 
Figuur 12: Aspekte van groepsproses (French, 1983:238, Kreigh \& Perko, 1983:303)

Aanwysing: Die groepleier maak ' $n$ regmerk in die blokkies hieronder van persone wat met mekaar in interaksie tree.

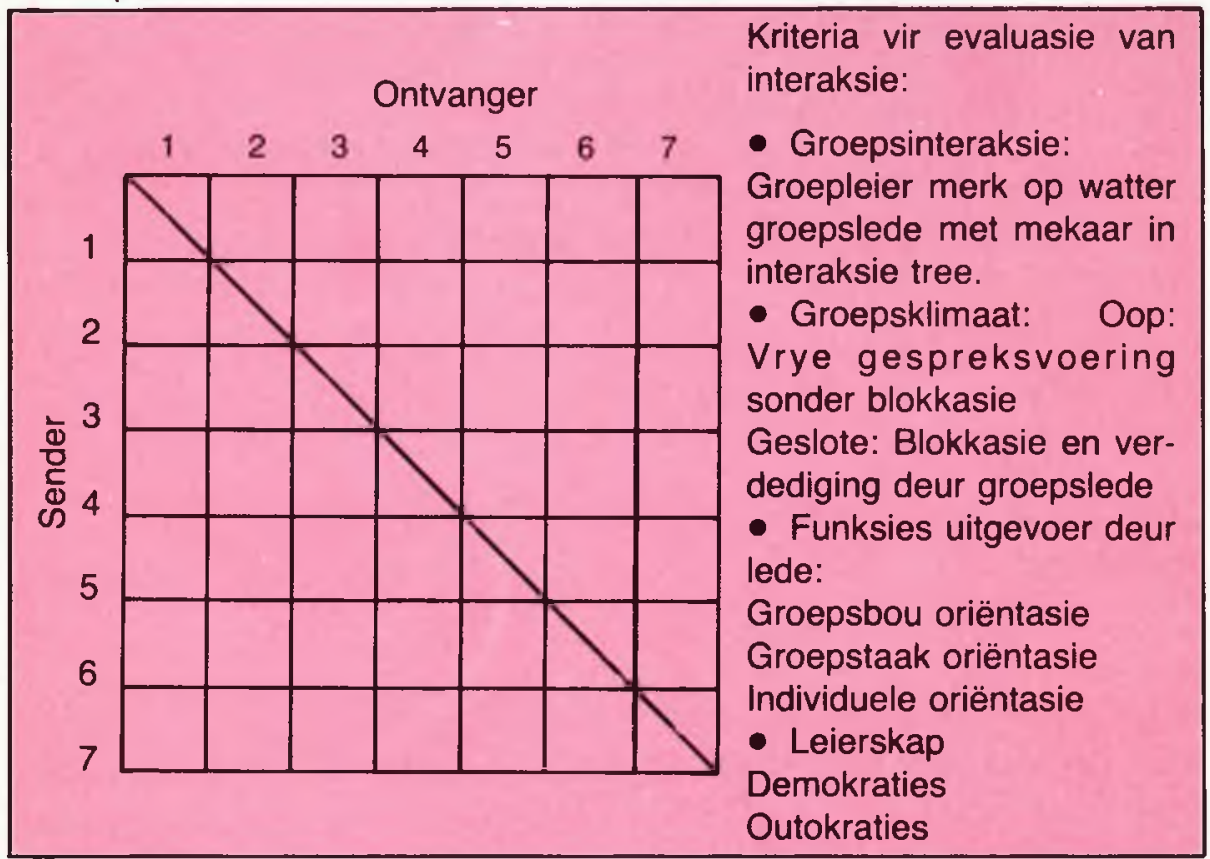

Figuur 13: Aspekte van die Terapeutiese milieu (Kreigh \& Perko, 1983:49)

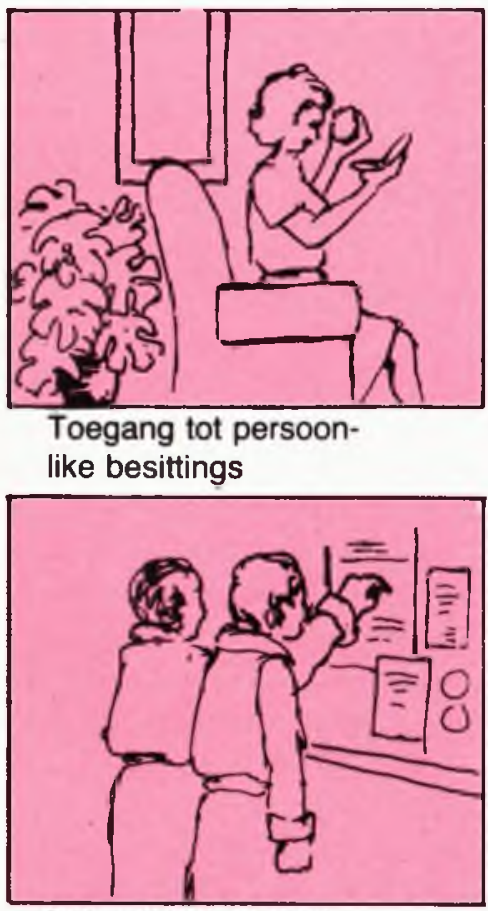

Geleentheid vir deel-

name en betrokkenheid

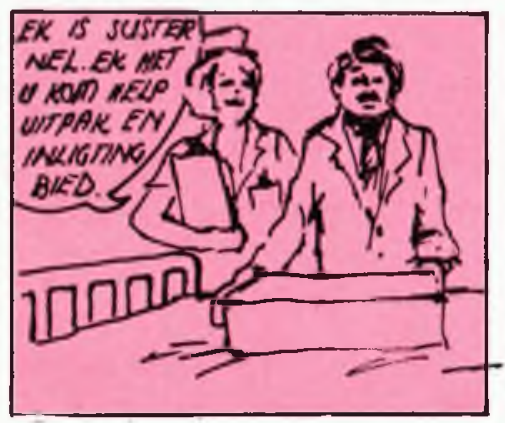

Bevordering van gevoelens van se kuriteit en vertroue

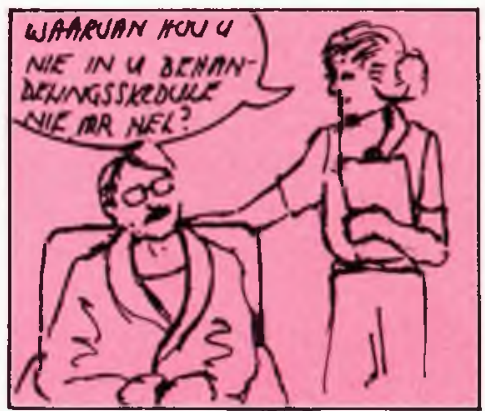

Geleentheid om deel te neem aan eie behandelingsplan

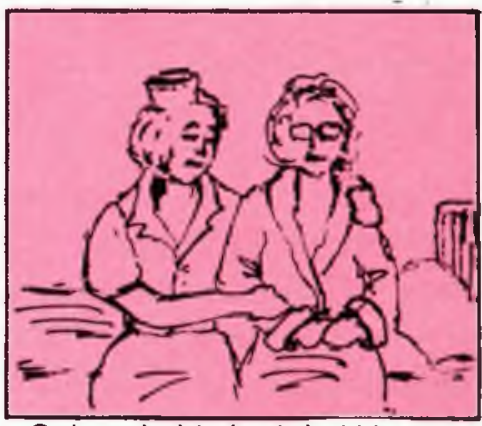

Geleentheid vir uitdrukking en aanvaarding van gevoelens

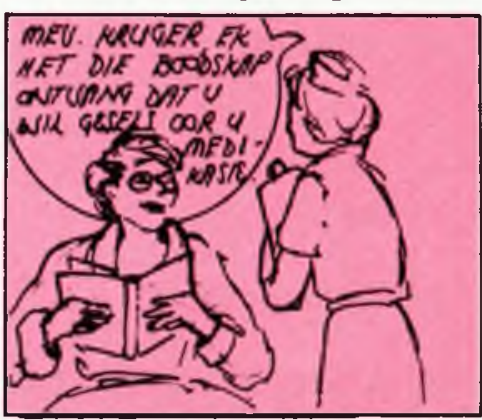

Erkenning van individu deur op behoeftes te reageer.

\section{Terapeutiese Milieu}

Die psigiatriese verpleegkundige stel doelbewus onmiddellike lewensituasies en ervarings daar wat gemik is op probleemoplossing, oplossing van konflik en die implementering van spanningsverminderingsdoelstellings. (Kreigh \& Perko, 1983:47-49, Haber, Leach, Schudy \& Sideleau, 1978:8).

\section{Krisisingryping en-}

\section{ondersteuning}

Ingryping deur die psigiatriese verpleegkundige in 'n krisis is gemik op die herstel van ekwilibrium by persone wat as redelik gesond beskou was voor die ontwikkeling van die krisis wat hulle tydelik buite aksie gestel het.

Die psigiatriese verpleegkundige gebruik krisisondersteuning om geestesongestelde pasiënte wat in krisis verkeer te help. (Kaplan \& Sadock 1982:763, Burgess \& Lazare, 1976:154 173. Wilson \& Kneisl, 1983:274, Brammer, 1979:109-125, Mereness \& Taylor, 1978:477-480, Murray \& Heulskoetter, 1983:245-250).

\section{Geestesgesondheidsvoorligting.}

Die psigiatriese verpleegkundige voorsien kennis en insig oor enige aspekte betreffende die bevordering van geestesgesondheid aan individue en groepe. (Murray \& Zetner, 1979, 152-183).

\section{TOEPASSING IN VERSKIL- LENDE VERPLEEGDIMEN- \\ SIES}

Op grond van die voorafgaande is dit duidelik dat psigiatriese verpleegvaardighede op persoonlike vlak, in verhouding met hulpbehoewendes en in die uitvoering van die verpleegkundige se alledaagse taak gebruik kan word.

Op persoonlike vlak dra die psigiatriese verpleegvaardighede by tot die verpleegkundige se persoonlike groei en ontwikkeling van potensiaal. Met die kennis, houdings en vaardighede is die verpleegkundige wat in ander areas van verpleegkunde betrokke is, in staat om positiewe interpersoonlike verhoudinge met haar medemens daar te stel sowel as om haarself professioneel en terapeuties te gebruik om individue-in-nood te help. Kennis en vaardighede in onderhoudsvoering, individuele- en groepsterapie, terapeutiese milieu daarstelling. krisisingryping en -ondersteuning en geestesgesondheidsvoorligting help die verpleegkundige om effektief die uitdagings in haar konták met kollegas en multiprofessionele spanlede, die bestuur van haar afdeling en die hantering van pasiënte die hoof te bied

Vervolg op p. 29 